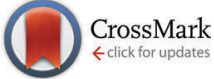

Cite this: Chem. Commun., 2017, 53,2954

Received 7th February 2017,

Accepted 10th February 2017

DOI: $10.1039 / \mathrm{c} 7 \mathrm{cc} 00982 \mathrm{~h}$

rsc.li/chemcomm

\section{Carbodiphosphorane mediated synthesis of a triflyloxyphosphonium dication and its reactivity towards nucleophiles $\dagger$}

\author{
S. Yogendra, ${ }^{a}$ F. Hennersdorf, ${ }^{a}$ A. Bauzá, ${ }^{b}$ A. Frontera, ${ }^{b}$ R. Fischer ${ }^{c}$ and \\ J. J. Weigand*a
}

\begin{abstract}
A carbodiphosphorane $\left(\left(\mathrm{Ph}_{3} \mathrm{P}\right)_{2} \mathrm{C}\right)$ mediated synthesis of the first triflyloxyphosphonium dication $\left(1^{2+}\right)$ bearing two electrophilic sites is presented. Depending on the nucleophile, $1^{2+}$ reacts selectively either at the sulfur atom of the triflyloxy moiety or at the directly attached phosphorus atom. In substitution reactions at the phosphorus atom the triflyloxy moiety serves as a leaving group and enables the synthesis of rare examples of pseudo-halophosphonium dications.
\end{abstract}

Carbodiphosphoranes as four electron donors with $\sigma^{-}$and $\pi$-symmetry are considered as strong donor ligands. ${ }^{1}$ Their donor abilities were recently used to prepare several main group Lewis acids, ${ }^{2}$ including the syntheses of phosphenium dications. ${ }^{3}$ Phosphonium cations are gaining strong reputation as very potent Lewis acids, ${ }^{4}$ particularly in the field of FLP chemistry, ${ }^{5}$ as organocatalyst ${ }^{6,7}$ for molecule transformations ${ }^{8}$ and as assisting group in boron based molecular receptors for selective anion complexation. ${ }^{9}$ Electron deficient phosphonium dications of type A bearing at least one electron withdrawing substituent $\mathrm{X}$ which can also act as a good leaving group should allow for facile substitution reactions at the phosphonium moiety, thus, should enable the synthesis of a variety of functionalized phosphonium cations (Scheme 1). In this respect, the well-established and conveniently accessible triflyloxy-group (OTf) comprises two important functions - firstly, it has electron withdrawing properties and secondly, the possibility to act as a suitable leaving group via liberation of the weakly coordinating triflate anion in nucleophilic substitution reactions. Thus, triflyloxy-substituted pnictogen derivatives such as $\mathrm{Ph}_{3} \mathrm{Pn}(\mathrm{OTf})_{2}$ $(\mathrm{Pn}=\mathrm{As}, \mathrm{Sb}$, and $\mathrm{Bi})$ were synthesized and used in nucleophilic substitution reactions with a series of Lewis bases. ${ }^{10}$ The related P-based $\left[\mathrm{Ph}_{3} \mathrm{P}-\mathrm{OTf}\right][\mathrm{OTf}]$ salt was suggested to form as an intermediate in the reaction of $\mathrm{Ph}_{3} \mathrm{P}(\mathrm{O})$ with $\mathrm{Tf}_{2} \mathrm{O}$ to give the

\footnotetext{
${ }^{a}$ Department of Chemistry and Food Chemistry, TU Dresden 01062 Dresden, Germany. E-mail: jan.weigand@tu-dresden.de

${ }^{b}$ Department of Chemistry, Universitat de les Illes Balears, Palma de Mallorca, Spain ${ }^{c}$ Department of Inorganic Chemistry, TU Graz, 8010 Graz, Austria

$\dagger$ Electronic supplementary information (ESI) available. CCDC 1517442-1517448, 1518258 and 1518259. For ESI and crystallographic data in CIF or other electronic format see DOI: 10.1039/c7cc00982h
}

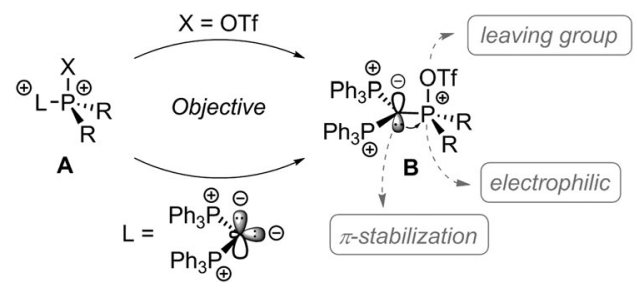

Scheme 1 Proposed synthetic route and reactivity of triflyloxyphosphonium dications of type $\mathbf{B}$.

well-known Hendrickson reagent $\left[\left(\mathrm{Ph}_{3} \mathrm{P}\right)_{2} \mathrm{O}\right][\mathrm{OTf}]_{2} ;^{11}$ however, to the best of our knowledge, the triflyloxyphosphonium cations of type $\left[\mathrm{R}_{3} \mathrm{P}-\mathrm{OTf}\right]^{+}$have never been isolated to date.

Thus, triflyloxyphosphonium dications of type $\mathbf{B}$ should readily undergo substitution reactions at the $\mathrm{P}_{(\mathrm{OTf})}$ atom by releasing the weakly coordinating triflate anion (Scheme 1). In this contribution, we present a carbodiphosphorane mediated synthesis of the first triflyloxyphosphonium salt $\mathbf{1}[\mathrm{OTf}]_{2}$ (Scheme 2), which enables the selective synthesis of a variety of (pseudo)halophosphonium salts.

The implementation of a phosphanyl moiety onto carbodiphosphorane $\left(\mathrm{Ph}_{3} \mathrm{P}\right)_{2} \mathrm{C}(2)$ was already reported in 1966 as a result of the reaction of 2 with $\mathrm{Ph}_{2} \mathrm{PCl}^{12}$ The formed salt $3[\mathrm{Cl}]$ is conveniently converted to the triflate salt via in situ addition of $\mathrm{Me}_{3}$ SiOTf. 3[OTf] is obtained as a colorless and air-stable powder in very good yields (90\%, Scheme 2). The ${ }^{31} \mathrm{P}\left\{{ }^{1} \mathrm{H}\right\}$ NMR spectrum of 3 [OTf] displays the expected $\mathrm{AX}_{2}$ spin system with the triplet resonance at $\delta\left(\mathrm{P}_{\mathrm{A}}\right)=-1.3 \mathrm{ppm}$ and the doublet resonance at

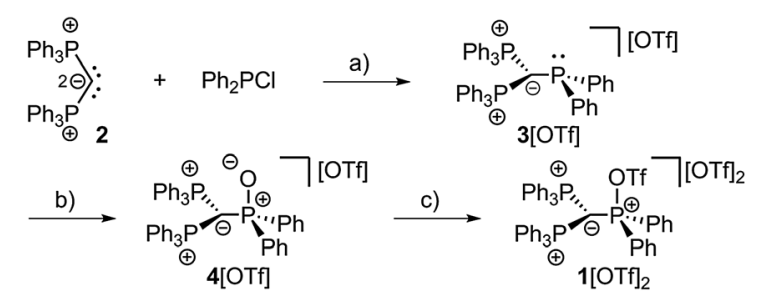

Scheme 2 Preparation of $3[\mathrm{OTf}], 4[\mathrm{OTf}]$ and $\mathbf{1}[\mathrm{OTf}]_{2} ;$ (a) $+\mathrm{Me}_{3} \mathrm{SiOTf}$, $-\mathrm{Me}_{3} \mathrm{SiCl}, \mathrm{C}_{6} \mathrm{H}_{5} \mathrm{~F}, \mathrm{rt}, 1 \mathrm{~h}, 90 \%$; (b) $+{ }^{t} \mathrm{BuO}_{2} \mathrm{H},-{ }^{t} \mathrm{BuOH} \mathrm{CH}_{2} \mathrm{Cl}_{2}, \mathrm{rt}, 30 \mathrm{~min}$, $97 \%$; (c) $+\mathrm{Tf}_{2} \mathrm{O}, \mathrm{C}_{6} \mathrm{H}_{5} \mathrm{~F}, \mathrm{rt}, 12 \mathrm{~h}, 98 \%$. 
$\delta\left(\mathrm{P}_{\mathrm{X}}\right)=26.4 \mathrm{ppm}\left({ }^{2} J_{\mathrm{PP}}=75 \mathrm{~Hz}\right) \cdot{ }^{13}$ The molecular structure of cation $3^{+}$displays the expected pyramidalized phosphanyl moiety and the trigonal planar arrangement of the substituents around the methanide moiety (angle sum: $360.00(2)^{\circ}$, Fig. 1). The $\mathrm{C}(1)-\mathrm{P}(2)$ and $\mathrm{C}(1)-\mathrm{P}(3)$ bonds (1.751(1) $\AA$ and 1.747(1) $\AA$ ) are shortened compared to other phosphonium salts $\left(\right.$ e.g. $\left[\mathrm{Ph}_{4} \mathrm{P}\right]^{+}: \mathrm{P}-\mathrm{C}_{\text {(average) }}$ $1.80(1) \AA)$ as a result of the negative hyperconjugation from the p-type lone pair of electrons at $\mathrm{C}(1)$ into the $\sigma^{*}\left(\mathrm{P}(2) / \mathrm{P}(3)-\mathrm{C}_{\mathrm{Ph}}\right)$ orbitals. ${ }^{14} 3$ [OTf] reacts cleanly with ${ }^{t} \mathrm{BuO}_{2} \mathrm{H}$ affording the phosphane oxide triflate salt 4[OTf] (yield: $96 \%)^{12}$ and displays, in contrast to $3[\mathrm{OTf}]$, an $\mathrm{A}_{2} \mathrm{X}$ spin system with resonances observed at $\delta\left(\mathrm{P}_{\mathrm{X}}\right)=26.5 \mathrm{ppm}$ and $\delta\left(\mathrm{P}_{\mathrm{A}}\right)=22.8 \mathrm{ppm}$. The ${ }^{2} J_{\mathrm{PP}}$ coupling constant of $18 \mathrm{~Hz}$ is much smaller in magnitude compared to that of $3[\mathrm{OTf}]\left({ }^{2} J_{\mathrm{PP}}=75 \mathrm{~Hz}\right)$ as a result of the coupling between two tetra-coordinated $\mathrm{P}$ atoms. ${ }^{13}$ The molecular structure of cation $\mathbf{4}^{+}$ (Fig. 1) displays the expected distorted tetrahedral bonding environment for the $\mathrm{P}(1)$ atom with a typical $\mathrm{P}-\mathrm{O}$ bond length of $1.489(1) \AA^{15}$ The reaction of 4 [OTf] with one equivalent of triflic anhydride $\left(\mathrm{Tf}_{2} \mathrm{O}\right)$ leads to the formation of the highly moisture sensitive triflyloxyphosphonium triflate salt $\mathbf{1}[\mathrm{OTf}]_{2}$ in excellent yield (98\%, Scheme 2 ). We propose that the additional $\pi$-donor ability of the $\left(\mathrm{Ph}_{3} \mathrm{P}\right)_{2} \mathrm{C}$ moiety leads to a sufficient stabilization of the cation $1^{2+}$ by increasing electron density at the $\mathrm{P}(1)$ atom, which consequently enhances the Lewis basicity of the $\mathrm{O}(1)$ atom. The synthesis of $\mathbf{1}[\mathrm{OTf}]_{2}$ succeeds also via the direct oxidation of 3 [OTf] with in situ generated $\mathrm{PhI}(\mathrm{OTf})_{2},{ }^{16}$ which serves as a strong oxidant and an OTf source at the same time. Cation $\mathbf{1}^{2+}$ is formed in solution in a spectroscopic yield of $73 \%$ according to ${ }^{31} \mathrm{P}$ NMR spectroscopy. The formation of significant amounts of side products ${ }^{17}$ hampers a high yielding isolation of $\mathbf{1}[\mathrm{OTf}]_{2}$ and, thus, makes the two step method, according to Scheme 2, more efficient. The
${ }^{31} \mathrm{P}\left\{{ }^{1} \mathrm{H}\right\}$ NMR spectrum of $\mathbf{1}[\mathrm{OTf}]_{2}$ displays an $\mathrm{A}_{2} \mathrm{X}$ spin system with a pronounced downfield shifted triplet for the $\mathrm{P}_{\mathrm{X}}$ atom $\left(\delta\left(\mathrm{P}_{\mathrm{X}}\right)=86.0 \mathrm{ppm} ;{ }^{2} J_{\mathrm{PP}}=20 \mathrm{~Hz}\right)$ compared to $4[\mathrm{OTf}]$. The electron withdrawing properties of the OTf-substituent cause a deshielding of the corresponding $\mathrm{P}_{\mathrm{X}}$ atom and explain this significant shift. This effect, however, does not influence the resonance observed for the $\mathrm{Ph}_{3} \mathrm{P}$-onio substituents $\left.\left(\delta\left(\mathrm{P}_{\mathrm{A}}\right)\right)=25.8 \mathrm{ppm}\right)$ and, thus, only a slight downfield shift of $\Delta \delta=3.0 \mathrm{ppm}$ is observed. The ${ }^{19} \mathrm{~F}$ NMR spectrum reveals two sharp singlets at $\delta=-71.9 \mathrm{ppm}$ and $-78.5 \mathrm{ppm}$ for the bonded OTf-group and for the noncoordinated OTf anions, respectively. No dynamic behavior for the OTf-substituent in solution at temperatures from $-28{ }^{\circ} \mathrm{C}$ to $72{ }^{\circ} \mathrm{C}$ is observed as evidenced by variable temperature ${ }^{31} \mathrm{P}-/{ }^{19} \mathrm{~F}$ NMR spectroscopy. ${ }^{17}$ The molecular structure of $\mathbf{1}^{2+}$ reveals a distorted tetrahedral bonding environment at the $\mathrm{P}(1)$ atom with a pronounced shortening of the $\mathrm{C}(1)-\mathrm{P}(1)$ bond $(1.731(5) \AA)$ and elongation of the $\mathrm{C}(1)-\mathrm{P}(2)(1.789(5) \AA)$ and $\mathrm{C}(1)-\mathrm{P}(3)(1.777(5) \AA)$ bonds, in contrast to those in cations $3^{+}$and $4^{+}$(Fig. 1 and Table 1). The shortening of the $\mathrm{C}(1)-\mathrm{P}(1)$ bond is a result of an increased negative hyperconjugation from the p-type lone pair of electrons at $\mathrm{C}(1)$ into the $\sigma^{*}(\mathrm{P}(1)-\mathrm{O}(1))$ orbital. This redistribution of electron densities from the $\mathrm{C}(1)$ lone pair in benefit to the $\mathrm{P}(1)$ atom may account for the strong stabilization of the electron deficient triflyloxyphosphonium moiety. The $\mathrm{P}-\mathrm{O}$ bond in $\mathbf{1}^{2+}$ ( $\mathrm{P}(1)-\mathrm{O}(1)$ 1.676(4) $\mathrm{A}$ ) is exceptionally long for a typical $\mathrm{P}^{\mathrm{V}}-\mathrm{O}$ bond $\left(c f\right.$. Hendrickson reagent $\left[\left(\mathrm{Ph}_{3} \mathrm{P}\right)_{2} \mathrm{O}\right]^{2+}: 1.597(3) \AA$, 1.598(4) $\left.\AA^{18}\right)$ but an expected consequence of the above-mentioned donation of electron density into the $\sigma^{*}(\mathrm{P}(1)-\mathrm{O}(1))$ orbital (vide supra). This effect is even more pronounced by the highly electron withdrawing properties of the triflyl group - $\mathrm{SO}_{2} \mathrm{CF}_{3}$ - and leads to an elongated and strongly activated $\mathrm{P}-\mathrm{O}$ bond. Similarly, the $\mathrm{O}(1)-\mathrm{S}(1)$ bond

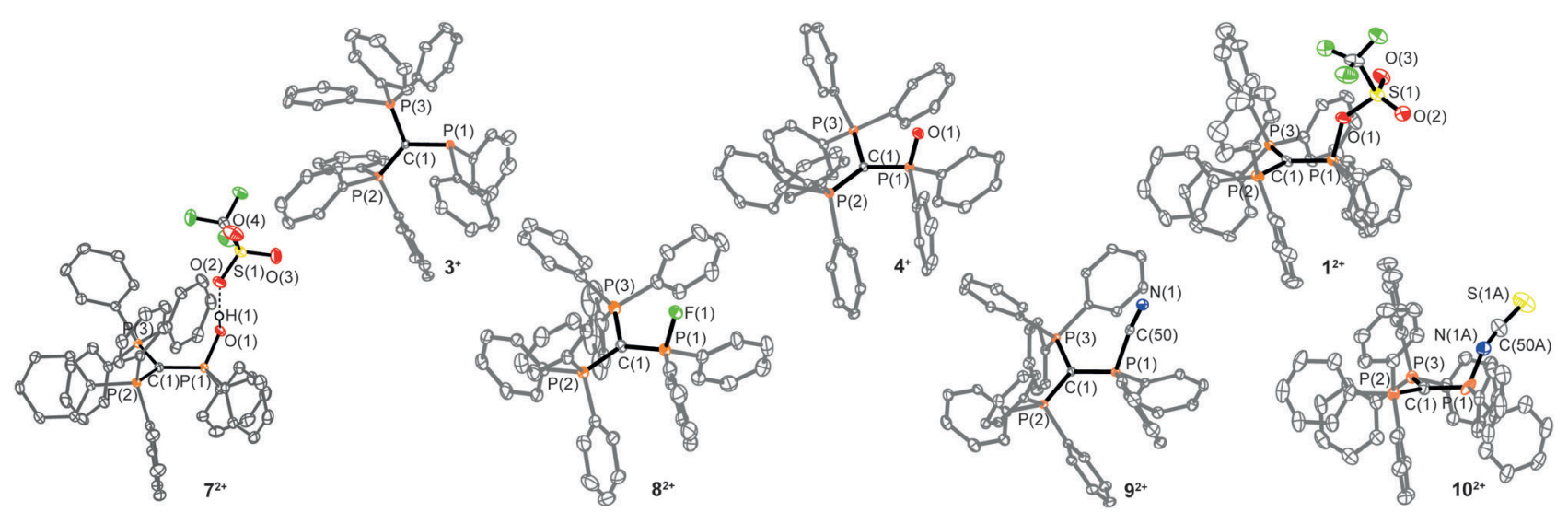

Fig. 1 Molecular structures of $3^{+}, 4^{+}, 1^{2+}, 7^{2+}, 8^{2+}, 9^{2+}$ and $10^{2+}$ (hydrogen atoms are omitted for clarity and thermal ellipsoids are displayed at $50 \%$ probability).

Table 1 Selected bond length for crystallographically characterized cations $3^{+}, 4^{+}, 1^{2+}, 7^{2+}, 8^{2+}, 9^{2+}$ and $10^{2+}$

\begin{tabular}{llllllll}
\hline Bond length in $\AA$ & $\mathbf{3}^{+}$ & $\mathbf{4}^{+}$ & $\mathbf{1}^{2+}$ & $7^{2+}$ & $\mathbf{8}^{2+}$ & $\mathbf{9}^{2+}$ \\
\hline $\mathrm{P}(1)-\mathrm{C}(1)$ & $1.811(1)$ & $1.803(2)$ & $1.731(5)$ & $1.754(1)$ & $1.721(3)$ & $1.754(1)$ \\
$\mathrm{P}(2)-\mathrm{C}(1)$ & $1.751(1)$ & $1.747(2)$ & $1.789(5)$ & $1.780(1)$ & $1.777(3)$ & $1.788(3)$ \\
$\mathrm{P}(3)-\mathrm{C}(1)$ & $1.747(1)$ & $1.754(2)$ & $1.777(5)$ & $1.775(1)$ & $1.784(3)$ & $1.780(1)$ & $1.748(5)$ \\
$\mathrm{P}(1)-\mathrm{X}$ & - & $\mathrm{X}=\mathrm{O}(1)$ & $\mathrm{X}=\mathrm{O}(1)$ & $\mathrm{X}=\mathrm{O}(1)$ & $\mathrm{X}=\mathrm{F}(1)$ & $\mathrm{X}=\mathrm{C}(50)$ & $\mathrm{X}=\mathrm{N}(1 \mathrm{~A})$ \\
& & $1.489(1)$ & $1.676(4)$ & $1.562(1)$ & $1.561(2)$ & $1.788(1)$ & $1.663(7)$
\end{tabular}




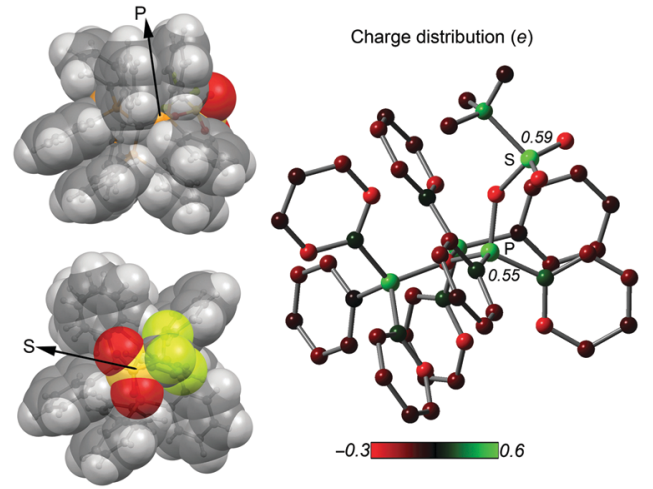

Fig. 2 Left: Two views of the space filling representation of $1^{2+}$; right: Mulliken charge distribution in $\mathbf{1}^{2+}$.

$(\mathrm{O}(1)-\mathrm{S}(1) 1.571(4) \AA)$ is also elongated compared to those observed for non-coordinating triflate anions $\left(\mathrm{S}-\mathrm{O}_{(\text {average) }} 1.43(3) \AA\right)$. This bonding environment at $\mathrm{P}_{(\mathrm{OTf})}$ in cation $\mathbf{1}^{2+}$ indicates an electron deficiency at the $\mathrm{S}(1)$ - and $\mathrm{P}(1)$ atoms, which was probed in reactions with a variety of nucleophiles. The computed charge distribution in cation $\mathbf{1}^{2+}$ confirms $\mathrm{P}(1)$ and $\mathrm{S}(1)$ as the most electrophilic sites with almost identical positive charges $(\mathrm{P}(1): 0.55 e, \mathrm{~S}(1): 0.59 e$, Fig. 2 , right). Thus, a preference for a nucleophilic attack at the $\mathrm{P}(1)$ or $\mathrm{S}(1)$ atom by charge discrimination is not likely. However, the space-filling representation of cation $\mathbf{1}^{2+}$ (Fig. 2, left) indicates a significant difference between both electrophilic centers with regard to their accessibility. The $\mathrm{P}(1)$ atom is sterically shielded by the close proximity of three phenyl rings which makes it less accessible for a nucleophilic attack. In contrast, the $\mathrm{S}(1)$ atom of the triflyloxy moiety is by far more exposed, which consequently allows a better interaction with nucleophiles. As a consequence, a size discrimination of cation $\mathbf{1}^{2+}$ in the reaction with nucleophiles can be anticipated. To probe our hypothesis, $\mathbf{1}[\mathrm{OTf}]_{2}$ was reacted with selected nucleophiles (Scheme 3). Bulky substituents react preferably at the $\mathrm{S}(1)$ atom of cation $\mathbf{1}^{2+}$ and, thus, $1[\mathrm{OTf}]_{2}$ gives in a quantitative reaction with 4-dimethylaminiopyridine (DMAP) the 1-triflyl-4-dimethylaminopyridinium salt 5[OTf] and $4[\mathrm{OTf}]$ as a result of the nucleophilic substitution at the $\mathrm{S}(1)$ atom and transfer of the $\mathrm{SO}_{2} \mathrm{CF}_{3}$-group to DMAP (I). Two sets of single crystals of $5[\mathrm{OTf}]$ suitable for X-ray diffraction were obtained at different temperatures $\left(-30^{\circ} \mathrm{C}\right.$ and $\left.21^{\circ} \mathrm{C}\right)$ displaying two monoclinic polymorphs that vary by their packing mode in the crystal structure $\left(C 2 / c v\right.$ vs. $P 2_{1} / n$; for further details, see the ESI $\left.\dagger\right)$. Similar to the reaction with DMAP, two equivalents of triphenylphosphane oxide $\left(\mathrm{Ph}_{3} \mathrm{P}(\mathrm{O})\right)$ react with $\mathbf{1}[\mathrm{OTf}]_{2}$ cleanly to give the Hendrickson reagent $\left[\left(\mathrm{Ph}_{3} \mathrm{P}\right)_{2} \mathrm{O}\right][\mathrm{OTf}]_{2}\left(6[\mathrm{OTf}]_{2}\right)$ and $4[\mathrm{OTf}](\mathrm{II})$. Phenol is converted in a $1: 1$ reaction into phenyltriflate and the hydroxyphosphonium salt $7[\mathrm{OTf}]_{2}(\mathrm{III}) .7[\mathrm{OTf}]_{2}$ displays a rare example of a hydroxyphosphonium dication and can be alternatively prepared directly via the protonation of 4 [OTf] with HOTf (yield: $83 \%$ ). Small nucleophiles should interact with dication $\mathbf{1}^{2+}$ at the $\mathrm{P}(1)$ atom preferably via elimination of the triflate anion. $1[\mathrm{OTf}]_{2}$ reacts cleanly with $\mathrm{AgF}$ to give the fluorophosphonium salt $8[\mathrm{OTf}]_{2}$ and AgOTf (IV), with $\mathrm{Me}_{3} \mathrm{SiCN}$ to the cyanophosphonium triflate $9[\mathrm{OTf}]_{2}$ accompanied by the liberation of $\mathrm{Me}_{3} \mathrm{SiOTf}(\mathbf{V})$, and with $\mathrm{NH}_{4} \mathrm{SCN}$ to yield the isothiocyanatophosphonium triflate $\mathbf{1 0}[\mathrm{OTf}]_{2}$ and $\mathrm{NH}_{4} \mathrm{OTf}$. We have computed theoretically for $\mathrm{F}^{-}, \mathrm{CN}^{-}, \mathrm{SCN}^{-}$, DMAP and $\mathrm{Ph}_{3} \mathrm{P}(\mathrm{O})$ both possible

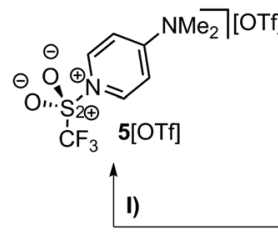

$6[\mathrm{OTf}]_{2}$

II)
$\left[\left(\mathrm{Ph}_{3} \mathrm{P}\right)_{2} \mathrm{O}\right][\mathrm{OTf}]_{2}$

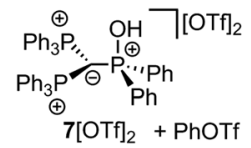

III)

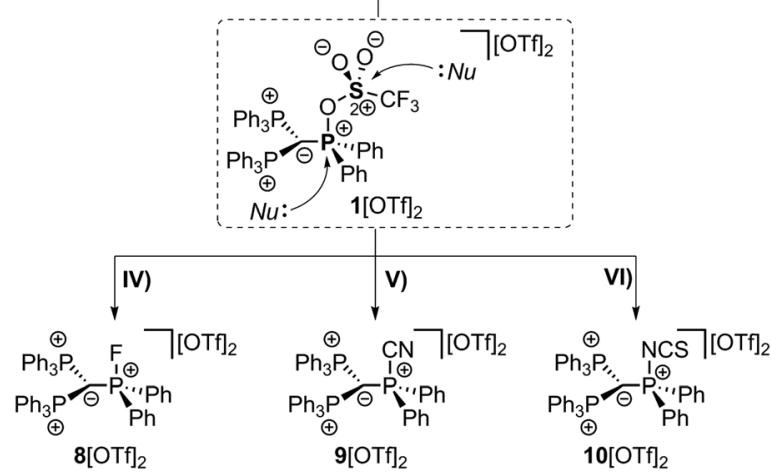

Scheme 3 Reactions of $\mathbf{1}[\mathrm{OTf}]_{2}$ with different nucleophiles; (I) +DMAP, $-4[\mathrm{OTf}]$, yield (5[OTf]): $90 \% *$; (II) $+\mathrm{Ph}_{3} \mathrm{P}(\mathrm{O}),-4[\mathrm{OTf}]$, quant. conversion**; (III) $+\mathrm{PhOH}$, quant. conversion**; (IV) $+\mathrm{AgF},-\mathrm{AgOTf}, 82 \% *$; (V) $+\mathrm{Me}_{3} \mathrm{SiCN}$, $-\mathrm{Me}_{3} \mathrm{SiOTf}, 88 \% *$, $(\mathrm{VI})+\mathrm{NH}_{4} \mathrm{SCN},-\mathrm{NH}_{4} \mathrm{OTf}, 73 \% *$; (isolated yields are marked with *; by ${ }^{31} \mathrm{P} /{ }^{19} \mathrm{~F}$ NMR spectroscopy $\left.{ }^{* *}\right) .{ }^{17}$

Table 2 Reaction energies (in $\mathrm{kcal} \mathrm{mol}^{-1}$ ) for the two possible nucleophilic attacks (P(1)- and S(1) atoms) given at the RI-BP86/def2-TZVP level of theory

\begin{tabular}{lrrrll}
\hline$\Delta E$ & $\mathrm{~F}^{-}$ & \multicolumn{1}{c}{$\mathrm{CN}^{-}$} & \multicolumn{1}{c}{$\mathrm{SCN}^{-}$} & \multicolumn{1}{c}{$\mathrm{DMAP}$} & $\mathrm{Ph}_{3} \mathrm{P}(\mathrm{O})$ \\
\hline $\mathrm{P}(1)$ & -76.5 & -48.1 & -40.6 & - & - \\
$\mathrm{S}(1)$ & -64.4 & -40.6 & -33.0 & -21.2 & -8.3 \\
$\Delta\left(E_{\mathrm{P}}-E_{\mathrm{S}}\right)$ & 12.1 & 7.5 & 7.6 & - & - \\
\hline
\end{tabular}

nucleophilic attacks (P(1) and S(1)) at the BP86-D3/def2-TZVP level of theory in a continuum solvent model (reaction energies are given in Table 2). ${ }^{17}$ The nucleophilic attacks of $\mathrm{F}^{-}, \mathrm{CN}^{-}$and $\mathrm{SCN}^{-}$are barrierless processes due to the dicationic nature of the electrophile. The substantial difference is that the nucleophilic attack at the $\mathrm{P}(1)$ atom is more exergonic than the attack at the $\mathrm{S}(1)$ atom (Table 2). This result further supports that small nucleophiles attack preferentially at the $\mathrm{P}(1)$ atom. For the sterically more demanding nucleophiles DMAP and $\mathrm{Ph}_{3} \mathrm{P}(\mathrm{O})$, only the attack at the $\mathrm{S}(1)$ atom is possible, although less favorable than the attack of the anions $\mathrm{F}^{-}, \mathrm{CN}^{-}$and $\mathrm{SCN}^{-}$at $\mathrm{P}(1)$ due to the stronger electrostatic attraction (see the ESI $\dagger$ ). Phosphonium salts $7-10[\mathrm{OTf}]_{2}$ could be conveniently isolated in good to very good yields $(73-88 \%)$ and show in the ${ }^{31} \mathrm{P}$ NMR spectra the characteristic $\mathrm{A}_{2} \mathrm{X}$ spin systems. The ${ }^{31} \mathrm{P}$ NMR spectrum of $7[\mathrm{OTf}]_{2}$ displays a triplet at $\delta\left(\mathrm{P}_{\mathrm{X}}\right)=50.3 \mathrm{ppm}$ and a doublet at $\delta\left(\mathrm{P}_{\mathrm{A}}\right)=23.9 \mathrm{ppm}$ $\left({ }^{2} J_{\mathrm{PP}}=21.0 \mathrm{~Hz}\right)$. The hydroxy group of $7[\mathrm{OTf}]_{2}$ is observable in the ${ }^{1} \mathrm{H}$ NMR spectrum, displaying a downfield shifted singlet resonance at $\delta(\mathrm{OH})=13.93 \mathrm{ppm}$. The molecular structures of $7^{2+}-\mathbf{1 0}^{2+}$ were also confirmed by X-ray analysis and are depicted in Fig. 1. The molecular structure of $7^{2+}$ reveals a distorted tetrahedral bonding environment at the $\mathrm{P}(1)$ atom.

Due to protonation the $\mathrm{P}-\mathrm{O}$ bond length $(\mathrm{P}(1)-\mathrm{O}(1)$ 1.562(1) $⿱$ A) is elongated compared to that of phosphane oxide $\mathbf{4}^{+}$but is still shorter than the $\mathrm{P}(1)-\mathrm{O}(1)$ bond in $\mathbf{1}^{2+}$. A short $\mathrm{O}-\mathrm{H} \cdots \mathrm{O}$ hydrogen 
bond is observed between the hydroxy group and one of the triflate anions $(\mathrm{O}(2)-\mathrm{H}(1) \cdots \mathrm{O}(2) \quad 2.549(2) \AA ⿻ \mathrm{~A}, \mathrm{O}(2)-\mathrm{H}(1) \cdots \mathrm{O}(2)$ $\left.173(3)^{\circ}\right){ }^{19}$ The fluorophosphonium salt $8[\mathrm{OTf}]_{2}$ displays in the ${ }^{31} \mathrm{P}\left\{{ }^{1} \mathrm{H}\right\}$ NMR spectrum a distinct dt resonance at $\delta\left(\mathrm{P}_{\mathrm{X}}\right)=$ $85.9 \mathrm{ppm}\left({ }^{1} J_{\mathrm{PF}}=1012 \mathrm{~Hz} ;{ }^{2} J_{\mathrm{PP}}=21 \mathrm{~Hz}\right)$ and a dd resonance at $\delta\left(\mathrm{P}_{\mathrm{A}}\right)=23.8 \mathrm{ppm}\left({ }^{3} J_{\mathrm{PF}}=15 \mathrm{~Hz}\right)$ with a dt resonance at $\delta(\mathrm{F})=$ -97.5 ppm in the ${ }^{19} \mathrm{~F}\left\{{ }^{1} \mathrm{H}\right\}$ NMR spectrum. The molecular structure of cation $\mathbf{8}^{\mathbf{2 +}}$ shows a distorted tetrahedral bonding environment for the $\mathrm{P}_{(\mathrm{F})}$ atom with a characteristic P-F bond length of 1.561(2) $\AA^{6}{ }^{6}$ Salt $9[\mathrm{OTf}]_{2}$ represents the first dicationic cyanophosphonium salt and displays in the ${ }^{31} \mathrm{P}$ NMR spectrum a triplet at $\delta\left(\mathrm{P}_{\mathrm{X}}\right)=19.7 \mathrm{ppm}$ and a doublet at $\delta\left(\mathrm{P}_{\mathrm{A}}\right)=25.5 \mathrm{ppm}\left({ }^{2} J_{\mathrm{PP}}=23 \mathrm{~Hz}\right)$. The ${ }^{13} \mathrm{C}\left\{{ }^{1} \mathrm{H}\right\} \mathrm{NMR}$ spectrum reveals the expected doublet at $\delta\left(\mathrm{C}_{(\mathrm{CN})}\right)=113.7 \mathrm{ppm}$ $\left({ }^{1} J_{\mathrm{CP}}=85 \mathrm{~Hz}\right)^{20}$ and the presence of the $\mathrm{CN}$ group is further supported by IR and Raman spectroscopy, which both display the characteristic cyanide stretching bands at 2191(w) $\mathrm{cm}^{-1},{ }^{21}$ and $2192(28) \mathrm{cm}^{-1}, 22$ respectively. The molecular structure of cation $\mathbf{9}^{\mathbf{2 +}}$ shows a distorted tetrahedral bonding environment for the $\mathrm{P}_{(\mathrm{CN})}$ atom. The $\mathrm{P}(1)-\mathrm{C}(50)$ bond (1.788(1) $\AA$ ) is in the typical range for a $\mathrm{P}-\mathrm{CN}$ bond length in phosphonium salts and compares well with related examples in the literature. ${ }^{23-25}$ The $\mathrm{P}(1)-\mathrm{C}(50)-\mathrm{N}(1)$ angle $\left(171.8(1)^{\circ}\right)$ is in comparison slightly more acute $\left(\left[\left(\mathrm{Me}_{2} \mathrm{~N}\right)_{3} \mathrm{PCN}\right]^{+} \quad\left(179.2(5)^{\circ}\right) ;^{23} \quad\left[\left(2,4,6-(\mathrm{MeO}) \mathrm{C}_{6} \mathrm{H}_{2}\right)_{3} \mathrm{PCN}\right]^{+}\right.$ $\left(180.0^{\circ}\right) ;{ }^{24}$ and $\mathrm{Ph}_{3} \mathrm{PCN}_{2}:\left(179.0(3)^{\circ}\right) .{ }^{25}$ The ${ }^{31} \mathrm{P}$ NMR spectrum of isothiocyanophosphonium salt $10[\mathrm{OTf}]_{2}$ shows a triplet at $\delta\left(\mathrm{P}_{\mathrm{X}}\right)=36.4 \mathrm{ppm}$ and a doublet at $\delta\left(\mathrm{P}_{\mathrm{A}}\right)=24.8 \mathrm{ppm}\left({ }^{2} J_{\mathrm{PP}}=22 \mathrm{~Hz}\right)$. The isothiocyanato group resonates in the ${ }^{13} \mathrm{C}\left\{{ }^{1} \mathrm{H}\right\}$ NMR spectrum as a doublet at $\delta(\mathrm{NCS})=115.7 \mathrm{ppm}\left({ }^{2} J_{\mathrm{CP}}=21 \mathrm{~Hz}\right)^{26}$ and the IR spectrum shows a strong band at $1956(\mathrm{~m}) \mathrm{cm}^{-1}$, typical for covalently bonded SCN-groups. ${ }^{27}$ Cation $\mathbf{1 0}^{2+}$ is the first crystallographically characterized example of an isothiocyanatophosphonium cation and displays a distorted tetrahedral bonding environment at the $\mathrm{P}_{(\mathrm{NCS})}$ atom. Its $\mathrm{P}(1)-\mathrm{N}(1 \mathrm{~A})$ bond length (1.663(7) $\AA$ ) is shorter than those of neutral tetra-coordinated isothiocyanate-substituted $\mathrm{P}^{\mathrm{V}}$ compounds $\left((\operatorname{ImN})_{2} \mathrm{P}(\mathrm{NCS}) \mathrm{S}(\mathrm{ImN}=\right.$ 1,3-bis(2,6-diisopropylphenyl)-imidazol-2-imine): $1.728(1) \AA{ }^{28}$ (ferrocene)P( $\left.\left.\mathrm{NMe}_{2}\right)(\mathrm{NCS}) \mathrm{S}: 1.700(5) \AA\right) ;{ }^{29}$ a slightly more acute $\mathrm{P}(1)-\mathrm{N}(1 \mathrm{~A})-\mathrm{C}(50 \mathrm{~A})$ angle $\left(148.9(6)^{\circ}\right)$ is observed $\left((\mathrm{ImN})_{2} \mathrm{P}(\mathrm{NCS}) \mathrm{S}\right.$ : $162.0(1)^{\circ}$, (ferrocene)P(NMe $\left.)_{2}(\mathrm{NCS}) \mathrm{S}: \quad 156.5(6)^{\circ}\right)$. Analogously to dications $1^{2+}$ and $7^{2+}-9^{2+}$, a shortened $\mathrm{C}(1)-\mathrm{P}(1)$ bond is observed as the result of the electronic congestion of the substituents (Table 1).

In summary, the preparation of the triflyloxyphosphonium dication $\mathbf{1}^{2+}$ bearing two electrophilic sites that can be selectively addressed by nucleophiles has been achieved. Thus, large nucleophiles react exclusively with the triflyl-moiety via the transfer of the $\mathrm{SO}_{2} \mathrm{CF}_{2}$ group, whereas the reaction with small nucleophiles results in a substitution reaction at the $\mathrm{P}_{(\mathrm{OTf})}$ atom, consequently releasing the triflate anion. This renders dication $\mathbf{1}^{\mathbf{2 +}}$ a suitable reaction platform for the synthesis of functionalized phosphonium salts, as demonstrated by the isolation of various (pseudo)halophosphonium dications. The facile functionalization based on dication $\mathbf{1}^{\mathbf{2 +}}$ allows the precise design and preparation of valuable Lewis acidic phosphonium cations.

This work was supported by the Fonds der Chemischen Industrie (FCI, Kekulé scholarship for F. H.) and ERC (ERC starting grant
SynPhos: 307616). A. B. and A. F. thank DGICYT of Spain (projects CTQ2014-57393-C2-1-P and CONSOLIDER INGENIO CSD201000065, FEDER funds) for funding.

\section{References}

1 (a) W. Petz, Coord. Chem. Rev., 2015, 291, 1; (b) F. Tonner, F. Oxler, B. Neumüller, W. Petz and G. Frenking, Angew. Chem., Int. Ed., 2006, 45, 8038; (c) F. Ramirez, N. B. Desai, B. Hansen and N. McKelvie, J. Am. Chem. Soc., 1961, 83, 3539.

2 (a) W.-C. Chen, C.-Y. Lee, B.-C. Lin, Y.-C. Hsu, J.-S. Shen, C.-P. Hsu, G. P. A. Yap and T.-G. Ong, J. Am. Chem. Soc., 2013, 136, 914; (b) S. Khan, G. Gopakumar, W. Thiwl and M. Alcarazo, Angew. Chem., Int. Ed., 2013, 52, 5644; (c) B. Inés, M. Patil, J. Carreras, R. Goddard, W. Thiel and M. Alcarazo, Angew. Chem., Int. Ed., 2011, 50, 8400.

3 (a) M. Q. Y. Tay, G. Ilic, U. W. Zwanziger, Y. Lu, R. Ganguly, L. Ricard, G. Frison, D. Carmichael and D. Vidovic, Organometallics, 2016, 35, 439; (b) M. Q. Y. Tay, Y. Lu, R. Ganguly and D. Vidovic, Angew. Chem., Int. Ed., 2013, 52, 3132.

4 (a) J. M. Bayne and D. W. Stephan, Chem. Soc. Rev., 2016, 45, 765; (b) F. P. Gabbaï, Science, 2013, 341, 1348.

5 L. J. Hounjet, C. B. Caputo and D. W. Stephan, Angew. Chem., Int. Ed., 2012, 51, 4714.

6 C. B. Caputo, D. Winkelhaus, R. Dobrovetsky, L. J. Hounjet and D. W. Stephan, Dalton Trans., 2015, 44, 12256.

7 (a) M. Pérez, L. J. Hounjet, C. B. Caputo, R. Dobrovetsky and D. W. Stephan, J. Am. Chem. Soc., 2013, 135, 18308; (b) C. B. Caputo, L. J. Hounjet, R. Dobrovetsky and D. W. Stephan, Science, 2013, 341, 1374; (c) T. Werner, Adv. Synth. Catal., 2009, 351, 1469.

8 (a) D. Winkelhaus, M. H. Holthausen, R. Dobrovetsky and D. W. Stephan, Chem. Sci., 2015, 6, 6367; (b) J. J. Weigand, N. Burford, A. Decken and A. Schulz, Eur. J. Inorg. Chem., 2007, 4868-4872.

9 (a) H. Zhao, L. A. Leamer and F. P. Gabbaï, Dalton Trans., 2013, 42, 8164; (b) Y. Kim and F. P. Gabbaï, J. Am. Chem. Soc., 2009, 131, 3363; (c) M. H. Lee, T. Agou, J. Kobayashi, T. Kawashima and F. P. Gabbaï, Chem. Commun., 2007, 1133-1135.

10 (a) A. P. M. Robertson, N. Burford, R. McDonald and M. J. Ferguson, Angew. Chem., Int. Ed., 2014, 53, 3480; (b) M. Donath, M. Bodensteiner and J. J. Weigand, Chem. - Eur. J., 2014, 20, 17306.

11 (a) J. B. Hendrickson and S. M. Schwartzman, Tetrahedron Lett., 1975, 4, 277; (b) A. Aaberg, T. Gramstad and S. Husebye, Tetrahedron Lett., 1979, 24, 2263.

12 Synthesis of $3[\mathrm{Cl}]$ and subsequent oxidation with ${ }^{t} \mathrm{BuO}_{2} \mathrm{H}$ to give $4[\mathrm{Cl}]$ are reported in the following ref.: G. H. Birum and C. N. Matthews, J. Am. Chem. Soc., 1966, 88, 4198.

13 For other ${ }^{2} J_{\mathrm{PP}}$ coupling constants, see: A.-M. Caminade, E. Ocando, J.-P. Majoral, M. Cristante and G. Bertrand, Inorg. Chem., 1986, 25, 712.

14 T. Leyssens and D. Peeters, J. Org. Chem., 2008, 73, 2725.

15 G. Bandoli, G. Bortolozzo, D. A. Clemente, U. Croatto and C. Panattoni, J. Chem. Soc. A, 1970, 2778.

16 T. P. Pell, S. A. Chouchman, S. Ibrahim, D. J. D. Wilson, B. J. Smith, P. J. Barnard and J. L. Dutton, Inorg. Chem., 2012, 51, 13034.

17 For details, see ESI $\dagger$.

18 S.-L. You, H. Razavi and J. W. Kelly, Angew. Chem., Int. Ed., 2003, 42, 83. 19 P. A. Frey, Magn. Reson. Chem., 2001, 39, S190.

20 J. J. Weigand, K.-O. Feldmann and F. D. Henne, J. Am. Chem. Soc., 2010, 132, 16321.

21 R. E. Kitson and N. E. Griffith, Anal. Chem., 1952, 24, 334.

22 H. Gou, B. L. Yonke, A. Epshteyn, D. Y. Kim, J. S. Smith and T. A. Strobel, J. Chem. Phys., 2015, 142, 194503.

23 N. A. Barnes, S. M. Godfrey, R. T. A. Halton, R. G. Pritchard, Z. Safi and J. M. Sheffield, Dalton Trans., 2007, 3252.

24 N. A. Barnes, S. M. Godfrey, R. T. A. Halton, S. Law and R. G. Prichard, Angew. Chem., Int. Ed., 2006, 45, 1272.

25 S. M. Godfrey, C. A. McAuliffe, R. G. Pritchard and J. M. Sheffield, J. Chem. Soc., Dalton Trans., 1998, 1919.

26 M. Giffard, J. Cousseau and G. J. Martin, J. Chem. Soc., Perkin Trans. 2, 1985, 157.

27 E. Lieber, C. N. R. Rao and J. Ramachandran, Spectrochim. Acta, 1959, 13, 296.

28 F. Dielmann and G. Bertrand, Chem. - Eur. J., 2015, 21, 191.

29 M. R. S. Foreman, A. M. Z. Slawin and J. D. Woollins, Chem. Commun., 1997, 1269. 